\title{
Activation of Alpha 7 Cholinergic Nicotinic Receptors Reduce Blood-Brain Barrier Permeability following Experimental Traumatic Brain Injury
}

\author{
Pramod K. Dash, Jing Zhao, Nobuhide Kobori, John B. Redell, Michael J. Hylin, Kimberly N. Hood, \\ and Anthony N. Moore \\ Department of Neurobiology and Anatomy, McGovern Medical School, The University of Texas Health Science Center at Houston, Houston, Texas 77030
}

Traumatic brain injury (TBI) is a major human health concern that has the greatest impact on young men and women. The breakdown of the blood- brain barrier (BBB) is an important pathological consequence of TBI that initiates secondary processes, including infiltration of inflammatory cells, which can exacerbate brain inflammation and contribute to poor outcome. While the role of inflammation within the injured brain has been examined in some detail, the contribution of peripheral/systemic inflammation to TBI pathophysiology is largely unknown. Recent studies have implicated vagus nerve regulation of splenic cholinergic nicotinic acetylcholine receptor $\alpha 7$ (nAChRa7) signaling in the regulation of systemic inflammation. However, it is not known whether this mechanism plays a role in TBI-triggered inflammation and BBB breakdown. Following TBI, we observed that plasma TNF- $\alpha$ and IL-1 $\beta$ levels, as well as BBB permeability, were significantly increased in nAChRa7 null mice $\left(\mathrm{Chrna}^{-1-}\right)$ relative to wild-type mice. The administration of exogenous IL- $1 \beta$ and TNF- $\alpha$ to brain-injured animals worsened Evans Blue dye extravasation, suggesting that systemic inflammation contributes to TBI-triggered BBB permeability. Systemic administration of the nAChRa7 agonist PNU-282987 or the positive allosteric modulator PNU-120596 significantly attenuated TBI-triggered BBB compromise. Supporting a role for splenic nAChRa7 receptors, we demonstrate that splenic injection of the nicotinic receptor blocker $\alpha$-bungarotoxin increased BBB permeability in brain-injured rats, while PNU-282987 injection decreased such permeability. These effects were not seen when $\alpha$-bungarotoxin or PNU-282987 were administered to splenectomized, brain-injured rats. Together, these findings support the short-term use of nAChRa7-activating agents as a strategy to reduce TBI-triggered BBB permeability.

Key words: blood-brain barrier breakdown; controlled cortical impact brain injury; inflammatory cytokines; secondary TBI pathology

\section{Significance Statement}

Breakdown of the blood- brain barrier (BBB) in response to traumatic brain injury (TBI) allows for the accumulation of circulating fluids and proinflammatory cells in the injured brain. These processes can exacerbate TBI pathology and outcome. While the role of inflammation in the injured tissue has been examined in some detail, the contribution of peripheral inflammation in $\mathrm{BBB}$ breakdown and ensuing pathology has not been well defined. We present experimental evidence to indicate that the stimulation of nicotinic acetylcholine $\alpha 7$ receptors (nAChRa7s) can reduce peripheral inflammation and BBB breakdown after TBI. These results suggest that activators of nAChRa7 may have therapeutic utility for the treatment of TBI.

\section{Introduction}

Traumatic brain injury (TBI) results from the transduction of energy into the brain from an outside source. Each year in the

Received Aug. 25, 2015; revised Jan. 25, 2016; accepted Jan. 29, 2016.

Author contributions: P.K.D. designed research; P.K.D., J.Z., N.K., J.B.R., M.J.H., K.N.H., and A.N.M. performed research; P.K.D., J.Z., N.K., J.B.R., M.J.H., K.N.H., and A.N.M. analyzed data; P.K.D., J.Z., J.B.R., and A.N.M. wrote the paper.

This research was supported by the Senator Lloyd and B.A. Bentsen Center for Stroke Research, and National Institutes of Health Grants NS-087149 and NS-088298.

The authors declare no competing financial interests.
United States, $\sim 1.7$ million people sustain a TBI. TBI predominately affects young men and women, the consequences of which can impair day-to-day activities and reduce quality of life (Bennett et al., 1989; Bazarian et al., 2005; Nolan, 2005; Heegaard and

Correspondence should be addressed to Pramod K. Dash, Department of Neurobiology and Anatomy, McGovern Medical School, P.0. Box 20036, The University of Texas Health Science Center at Houston, Houston, TX 77030 E-mail: p.dash@uth.tmc.edu.

M.J. Hylin's present address: Department of Psychology, Southern Illinois University, Carbondale, IL 62901. DOI:10.1523/JNEUROSCI.3197-15.2016

Copyright $\odot 2016$ the authors $\quad 0270-6474 / 16 / 362809-10 \$ 15.00 / 0$ 
Biros, 2007). Unfortunately, effective treatments to reduce TBI pathology and improve outcome are currently unavailable. The blood-brain barrier (BBB) is a key component of the neurovascular unit, and its integrity is critical for maintaining brain homeostasis and function. Brain endothelial cells and tight junction proteins within brain microcapillaries are major constituents of the BBB. TBI has been shown to increase BBB permeability by decreasing the levels of tight junction proteins as well as by causing the death of endothelial cells. Breakdown of the BBB is an important secondary TBI pathology as it can cause further brain damage by allowing the infiltration of inflammatory cells and the uncontrolled access of circulating fluid, proteins, and signaling molecules to affected brain tissues (Tanno et al., 1992; Stahel et al., 2000; Morganti-Kossmann et al., 2007; Zhao et al., 2007). These events exacerbate ongoing brain inflammation and can contribute to cerebral edema and increased intracranial pressure, leading to decreased cerebral blood flow, secondary tissue damage, brain herniation, and poor outcome (Raghupathi, 2004; Kochanek et al., 2015).

A number of studies have investigated brain inflammation in response to TBI and its contribution to BBB pathology (Sanderson et al., 1999; Morganti-Kossmann et al., 2002; Titus et al., 2013; de Rivero Vaccari et al., 2016). These studies have shown a shift in microglia polarization toward the proinflammatory M1 subtype, astrocyte activation, and increased production of inflammatory cytokines in the injured tissue (Loane et al., 2014; Turtzo et al., 2014). Although increases in circulating levels of cytokines, including interleukin (IL)- $1 \beta$, IL- 6 , and tissue necrosis factor- $\alpha$ (TNF- $\alpha$ ), have been observed after TBI, a few studies have suggested that some of these molecules are released into the circulation from the injured brain (Kossmann et al., 1997; Helmy et al., 2011). One study has reported that intraperitoneal injection of IL- $1 \beta$ to TBI rodents exacerbated behavioral and histopathological consequences, suggesting a detrimental role for systemic inflammatory signaling in TBI (Utagawa et al., 2008). However, the sources of systemic inflammation and its regulation after TBI are poorly understood.

The release of corticosterone after activation of the hypothalamic-pituitary-adrenal axis by the vagus nerve is a classic mechanism for the regulation of systemic inflammation. More recent studies have implicated vagus nerve activity, especially the efferent splenic component, in reducing systemic inflammation (Borovikova et al., 2000; Rosas-Ballina et al., 2008; Olofsson et al., 2012). Consistent with this, we have previously demonstrated that splenectomy markedly decreased TBI-triggered BBB permeability, suggesting a role for spleen-mediated systemic inflammation in BBB breakdown (Walker et al., 2010). Investigation into the mechanism of the anti-inflammatory action of vagus nerve stimulation has led to the formulation of the cholinergic antiinflammatory pathway (CAP) hypothesis in which vagus nerve activation indirectly stimulates nicotinic acetylcholine receptor $\alpha 7$ (nAChRa7) subunit on splenocytes, causing decreased production of proinflammatory cytokines (Pavlov and Tracey, 2006; Rosas-Ballina et al., 2011). The role of this mechanism in TBI-triggered inflammation and BBB permeability has not been tested. In the present study, we used $C h r n a 7^{-1-}$ mice, pharmacological agents, and immunohistochemical techniques to examine the role of nAChRa7 in TBI-triggered BBB permeability and inflammation.

\section{Materials and Methods}

Materials. PNU-282987 hydrate was purchased from Sigma-Aldrich. PNU-120596 and $\alpha$-bungarotoxin were obtained from Tocris Biosci- ence. Anti-von Willebrand factor antibodies were bought from AbD Serotec, whereas the anti-Claudin-5 antibody was obtained from Invitrogen.

Animals. Male Sprague Dawley rats (275-300 g) and male C57BL/6 mice (25-30 g) were purchased from Harlan Laboratories. Splenectomized rats were obtained from Harlan Laboratories and allowed to rest for $10 \mathrm{~d}$ before experimental manipulation. Chrna ${ }^{-1-}$ mice (B6.129S7Chrna $^{7 \mathrm{tm} 1 \mathrm{Bay} / \mathrm{J}}$ ) were purchased from The Jackson Laboratory. Animals were housed under temperature-controlled conditions with a $12 \mathrm{~h}$ light/ dark cycle and ad libitum access to water and food. Animal protocols were approved by the Institutional Animal Welfare Committee and were in compliance with the National Institutes of Health Guide for the Care and Use of Laboratory Animals.

Controlled cortical impact injury. An electromagnetic controlled cortical impact (CCI) device was used to cause moderate brain injury in rats and mice, as has been previously described by us and others (Dixon et al., 1991; Zhao et al., 2007). This device uses an electromagnet to drive a piston at a preset speed onto the exposed surface of the brain. The depth of compression is controlled by zeroing the piston on the brain surface, then setting the machine to the desired depth. Rats were anesthetized with isoflurane, and craniectomies (6 $\mathrm{mm}$ in diameter) were made over the parietal cortices. Injury consisted of a single impact at $5.0 \mathrm{~m} / \mathrm{s}$ and a depth of $2.5 \mathrm{~mm}$ delivered to the right parietal cortex. Sham animals were anesthetized and received the incision, but not the craniectomy or impact. For mice, a $4 \mathrm{~mm}$ craniotomy was made after which a single impact $(1.0 \mathrm{~mm}$ deformation, $3.0 \mathrm{~m} / \mathrm{s}$ ) was delivered. Our previous experience using this electromagnetic device indicates that the injury parameters used for rats and mice generate comparable injury magnitudes, as indicated by equivalent righting responses (mice, $379.9 \pm 29.5 \mathrm{~s}$; rats, $405.3 \pm 17.42 \mathrm{~s}$ ). After injury, animals were allowed to recover in a warmed chamber before being returned to their home cages.

Randomization procedure. Before study initiation, animals were randomly assigned to either the vehicle or treatment group. Drug administration experiments were performed in a double-blind manner. Drugs and corresponding vehicle were prepared and labeled with a code (e.g., A and B) by an experimenter who was not involved in the execution of the study. A second experimenter performed the injections following the pre-established group designations. A third experimenter performed the data collection and analysis, after which the code was broken and the groups were statistically analyzed.

Splenic injections. Rats were deeply anesthetized with isoflurane, and then were prepared for sterile surgery using alternating scrubs of ethanol and Betadine. Before the incision, the site was infused with $0.25 \%$ bupivicaine as an analgesic. A $1 \mathrm{~cm}$ incision was made on the left side, and the spleen isolated as described previously (Moreno et al., 1998). A Hamilton syringe was used to inject the spleen at three sites along its axis with either PNU-282987 (30 $\mu \mathrm{g} /$ spleen), $\alpha$-bungarotoxin (500 ng/spleen), or an equal volume of vehicle $(100 \mu \mathrm{l})$. After completing the injections, the incision was sutured, and a topical antibiotic was applied. Twenty minutes after the infusion, rats were injured using the cortical impact injury device as described above.

Measurement of BBB permeability. BBB permeability was assessed by measuring the extravasation of Evans Blue dye as described by us previously (Zhao et al., 2007). Twenty-four hours after CCI injury, animals were anesthetized, and Evans Blue dye (3\% in saline) was injected slowly through the jugular vein $(4 \mathrm{ml} / \mathrm{kg})$ and allowed to circulate for $1.5 \mathrm{~h}$. After the circulation period, animals were given an overdose of pentobarbital $(100 \mathrm{mg} / \mathrm{kg})$ and transcardially perfused with PBS followed by PBS containing $4 \%$ paraformaldehyde. Brains were removed, ipsilateral hemispheres were cut into 2-mm-thick sections and incubated in $5 \mathrm{ml}$ of formamide at $55^{\circ} \mathrm{C}$ for $24 \mathrm{~h}$ (mouse brain slices were incubated in $1 \mathrm{ml}$ of formamide). After incubation, the formamide solution was cleared by centrifugation at $20,000 \times g$ for $20 \mathrm{~min}$. The supernatant was collected, and the optical density at $620 \mathrm{~nm}$ was measured to determine the relative amount of dye in each sample. A standard curve was run simultaneously to confirm the linearity of the recorded values. For each experiment, a group of injured reference animals (e.g., wild-type or vehicle-injected animals) was included in the experimental design to allow for the comparison of data across experiments. 
Blood collection and plasma preparation. At the indicated time points, animals were deeply anesthetized using sodium pentobarbital. Once the animal failed to respond to tail and foot pinch, the heart was exposed and blood was collected by cardiac puncture using a $16 \mathrm{Ga}$ needle attached to a $10 \mathrm{ml}$ syringe. EDTA was added as the anticoagulant. Platelet-poor plasma was prepared by centrifuging the blood at $1000 \times g$ for $10 \mathrm{~min}$ to remove the erythrocytes, leukocytes, and platelets. The supernatant solution was removed and centrifuged again at $10,000 \times g$ for $10 \mathrm{~min}$ to generate a platelet-poor plasma fraction. Plasma was aliquoted and frozen at $-80^{\circ} \mathrm{C}$ until needed.

ELISAs. Plasma cytokine levels were assessed using either magnetic bead-based multiplex ELISAs (BioPlex, Bio-Rad) or sandwich-style ELISAs. The range of the standards was based on the instructions of the vendors and on our previous experience with these techniques. The concentrations of each sample (assayed in triplicate) were calculated by comparison to the appropriate reference standard curve.

Western blots. High-mobility group box protein 1 (HMGB1) levels in serum were assayed using Western blots, as previously described (Bruchfeld et al., 2008). Briefly, equal volumes of plasma (50 $\mu \mathrm{l})$ were centrifuged on an Ultracel $100 \mathrm{~K}$ Amicon centrifugal filter for $15 \mathrm{~min}$ at $14,000 \times g$. The flow-thru was collected, $10 \mu \mathrm{l}$ of which was boiled in gel load buffer and run on SDS-PAGE gels. Following transfer to PVDF membranes (Immobilon P, Millipore) and blocking in 5\% BSA in Tris-buffered saline (TBS), membranes were incubated in anti-HMGB1 antibodies $(0.5 \mu \mathrm{g} / \mathrm{ml})$. Immunoreactivity was detected using a chemiluminescence substrate (SuperSignal West Pico, Life Technologies) followed by imaging and quantification using a LI-COR C-DIGIT imager. For normalization of protein recovery and loading, identical SDS-PAGE gels were run and stained with a colloidal Coomassie stain (GelCode Blue, Thermo Scientific). Bands within the stained gels were quantified using Image and compared across samples. The ratio for each individual sample compared with the average of all samples was calculated and used to correct the Western blot optical densities.

Immunohistochemistry. Twenty-four hours after injury, animals were killed, and their brains were removed and quickly frozen in $-80^{\circ} \mathrm{C}$ isopentane. Thirty-micrometer-thick coronal sections were prepared and mounted directly on gelatin-subbed slides. After air drying, the sections were fixed with $100 \%$ methanol for $20 \mathrm{~min}$ at $-20^{\circ} \mathrm{C}$ and then rinsed in TBS with $0.25 \%$ Triton X-100 (TBS-Tx) for $20 \mathrm{~min}$. The sections were blocked in $5 \%$ goat serum in TBS-Tx at room temperature for $1 \mathrm{~h} \mathrm{fol-}$ lowed by incubation with primary antibodies in $2.5 \%$ goat serum in TBS-Tx at $4^{\circ} \mathrm{C}$ for $24 \mathrm{~h}$ and then with species-specific secondary antibodies in $2.5 \%$ goat serum in TBS-Tx for $3 \mathrm{~h}$ at room temperature.

Fluorescence intensity quantification and cell counts. Fluorescence intensity was quantified essentially as described previously (Zhao et al., 2007). For quantification of von Willibrand factor (vWF) and Claudin-5 immunoreactivity, images of immunofluorescence were captured using a Zeiss Axiovert S100 Microscope through a Zeiss EC Plan-Neofluar 20×/ 0.5 lens and a MicroFIRE Camera. The parameters used for image acquisition (e.g., including laser power, iris size, brightness, and offset) were adjusted to minimize the background and optimize the signal using a tissue section from an injured animal. These parameters were then kept constant across all subsequent groups. ImageJ software was used to determine the fluorescence intensity based on the pictures. Three nonoverlapping regions in the ipsilateral cortex $(0.5 \mathrm{~mm}$ from injury core) from each section and two sections from each animal were used for fluorescent intensity quantification. One image from each section was taken medial, one was taken inferior, and one was taken lateral to the injury core to represent the entirety of the pericontusional area. The fluorescence intensities of the three regions were averaged for each section, and the two sections were averaged for each animal.

Myeloperoxidase (MPO)-positive neutrophils were counted using StereoInvestigator (MBF Bioscience). The medial component of pericontusioned cortex (cortical tissue from midline to the medial edge of the contusion, from the surface of the brain to the corpus callosum) was carefully outlined. Cells $(>8 \mu \mathrm{m}$ in diameter) were counted at $100 \times$ magnification by focusing down through the tissue and marking the soma as it became visible. The number of cells per square millimeter in tissue was calculated for three tissue sections from each animal and av- eraged. The identification of individual microglia in the injured brain tissue is complicated by the small size of their soma and the entanglement of their processes, making it difficult to identify the contours of individual cells. Thus, fluorescence intensity of CD86 immunoreactivity was used instead of performing cell counts. Images encompassing the dentate gyrus subfield of the ipsilateral hippocampus (approximately $-1.7 \mathrm{~mm}$ from bregma) were captured as described above. Three sections from each animal were immunostained and captured. The hilus, bounded by the inner and outer blades of the dentate gyrus, was carefully outlined. The mean fluorescent intensity from the three sections was averaged for each animal and used for statistical comparison.

Statistical analysis. All data were subjected to a Shapiro-Wilk normality test to ensure a normal distribution. Western blot and ELISA results were evaluated using either one-way or two-way ANOVAs. For data that did not have a normal distribution (i.e., serum IL-6 levels), a one-way ANOVA on ranks was used. The Holm-Sidak method for multiple comparisons post hoc test was used to determine the data points with significant differences. The optical densities of extracted Evans Blue dye were compared using a Student's two-tailed $t$ test for unpaired variables. Statistical analyses were performed using raw recorded data, before transformation into the percentage of control for presentation. Data were considered significant at $p<0.05$ and are presented as the mean \pm SEM.

\section{Results}

\section{Loss of nAChRa7 signaling exacerbates inflammation} after TBI

To examine whether $\mathrm{nAChRa7}$ plays a role in regulating the circulating levels of inflammatory molecules, we measured the levels of IL- $1 \beta$ and TNF- $\alpha$ in the plasma of wild-type and Chrna7 ${ }^{-1-}$ mice at $24 \mathrm{~h}(n=6)$ and 2 weeks $(n=3)$ after TBI. Groups of uninjured wild-type and Chrna7 ${ }^{-1-}$ mice $(n=8$ /genotype) were used as controls. Figure 1 shows the standard curves for these cytokines and their circulating levels as measured using a multiplex ELISA approach (Bioplex, Bio-Rad). Standard curves for IL- $1 \beta$ and TNF- $\alpha$ are shown in Figure 1, $A$ and $C$, respectively. The circulating levels of both IL- $1 \beta$ (interaction of group and day, $F=3.717, p=0.037$; Fig. $1 B)$ and TNF- $\alpha(F=3.913, p=$ 0.032 ; Fig. $1 D)$ were significantly enhanced in injured Chrna ${ }^{-1-}$ mice compared with injured wild-type controls. Further, when tissue sections obtained after injury were examined for markers of inflammatory cells $24 \mathrm{~h}$ after injury, increased expression of the M1-type microglial/macrophage marker CD86 was observed in the ipsilateral dentate gyrus of $\mathrm{Chrna}^{-1-}$ mice compared with wild-type injured mice (Fig. 1E). Fluorescent intensity quantification revealed that this immunoreactivity was significantly increased in injured $C h r n a 7^{-1-}$ mice compared with sham controls (Fig. $1 F ; H=5.96, p=0.025$ ). Likewise, numerous MPO-positive cells can be seen in the injured parietal cortex of the Chrna7 ${ }^{-1-}$ mice (Fig. 1E). MPO is the characteristic enzyme expressed by polymorphonuclear neutrophils, although its expression has been observed in microglia (Kinkade et al., 1983; Gray et al., 2008). MPO-positive neutrophils are typically amoeboid in shape, multinuclear, and $8-12 \mu \mathrm{m}$ in diameter (McCrory, 2002). When these cells were counted within the pericontusion cortex (midline to the medial edge of the contusion), a significant increase in the number of MPO-positive cells was found $24 \mathrm{~h}$ after injury in the injured $\mathrm{Chrna}^{-1-}$ mice (Fig. 1F; $H=7.26, p=0.004)$, suggesting an increase in infiltrating neutrophils.

\section{Loss of nAChRa7 signaling exacerbates BBB permeability after TBI}

To examine the status of the BBB in $C h r n a 7^{-1-}$ mice after CCI, wild-type and mutant animals were injured ( $n=5$ /group) and the extravasation of Evans Blue dye into the brain examined $24 \mathrm{~h}$ 
A
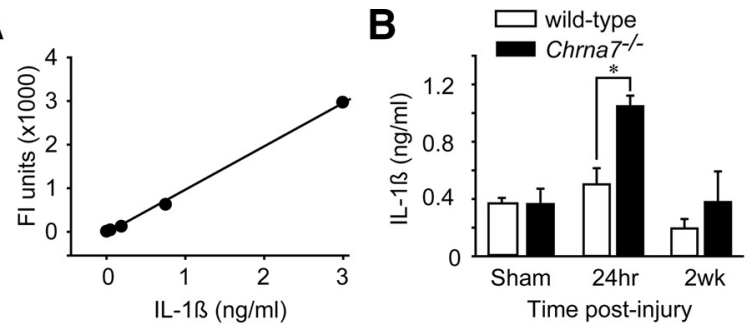

C

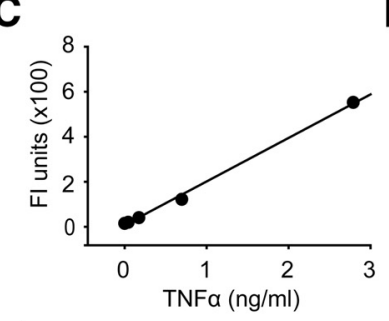

E Sham
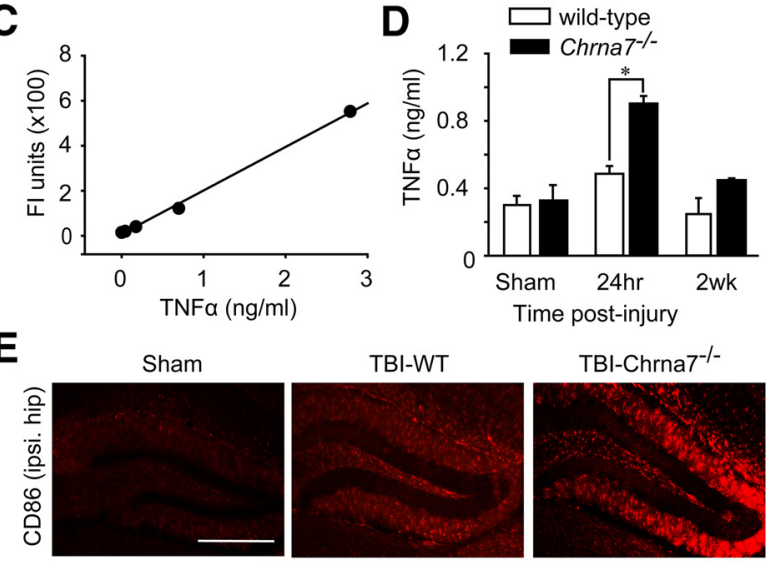

TBI-Chrna7-/-
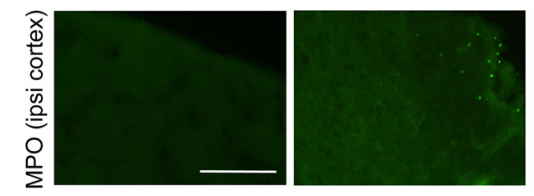

$\mathbf{F}$

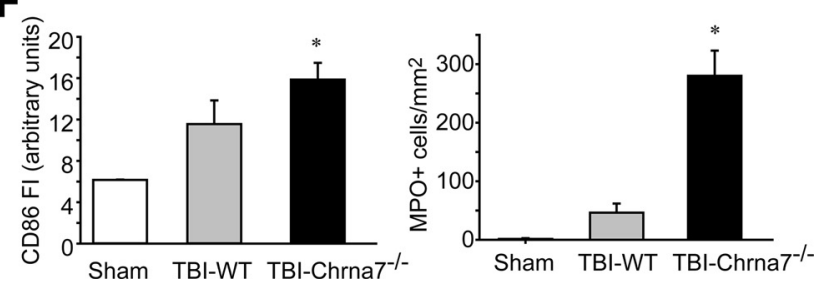

Figure 1. Loss of nAChRa7 increases the plasma levels of inflammatory cytokines and brain inflammatory markers after TBI. IL- $1 \beta$ and TNF- $\alpha$ levels were assessed by multiplex ELISA using plasma collected from wild-type (WT; (57BL/6) sham, wild-type TBI, Chrna ${ }^{-1-}$ sham, and Chrna ${ }^{-1-}$ TBI mice. $A$, Standard curve showing the linearity of the multiplex assay for IL-1 $\beta$. $B$, IL-1 $\beta$ levels were found to be significantly increased at the $24 \mathrm{~h}$ postinjury time point in Chrna7 ${ }^{-1-}$ mice $(n=6)$ compared with injured wild-type mice $(n=6)$. C, Standard curve demonstrating the linearity of the assay for TNF- $\alpha$. D, The postinjury plasma levels of TNF- $\alpha$ were found to be increased in mice lacking nAChRa7. E, F, Activated microglia (indicated by CD86 immunoreactivity) within the dentate gyrus of the ipsilateral hippocampus and neutrophil infiltration (indicated by MPO-positive cell counts) within the pericontusion region of the parietal cortex were found to be significantly enhanced in $\mathrm{Chrna}^{-1-} \mathrm{TBI}$ mice $(n=3)$ when examined $24 \mathrm{~h}$ after injury compared with sham $(n=3)$ mice. WT injured mice were not significantly different from sham controls. ${ }^{*} p<0.05$ by post hoc $t$ test. Data are presented as the mean \pm SEM. Scale bar, $500 \mu \mathrm{m}$.

after injury. Figure $2 A$ shows that, compared with injured wildtype mice, injured $\mathrm{Chrna}^{-1-}$ mice had significantly more Evans Blue dye extravasation in the ipsilateral cortex $(t=-4.911, p=$ 0.001 ), indicating worsened BBB permeability. As these mice had elevated levels of IL-1 $\beta$ and TNF- $\alpha$ after injury, we questioned whether exogenous administration of these cytokines to wildtype mice would be sufficient to exacerbate BBB permeability. Mice ( $n=6$ /group) were injured and randomly assigned to receive either a combination of IL- $1 \beta(8 \mu \mathrm{g} / \mathrm{kg})$ and TNF- $\alpha(8$ $\mu \mathrm{g} / \mathrm{kg}$ ) or an equal volume of vehicle. Injections were performed intravenously at $30 \mathrm{~min}$ and $22 \mathrm{~h}$ after injury. These doses and
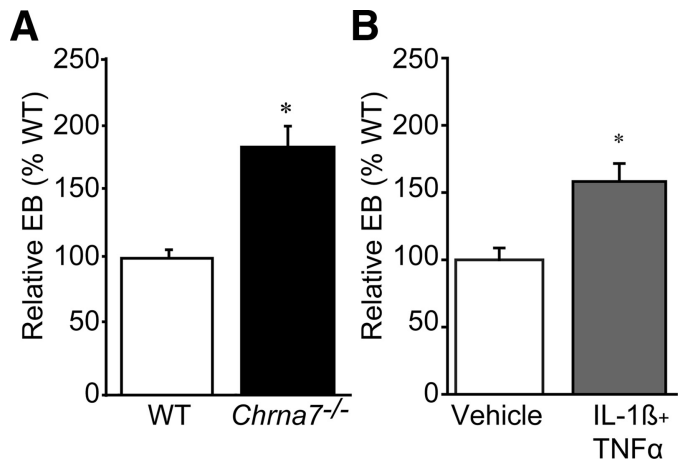

Figure 2. Loss of $n A C h R a 7$ increases BBB permeability after TBI, an effect mimicked by exogenous administration of proinflammatory cytokines. $A$, Compared with injured wild-type mice, injured Chrna7 ${ }^{-1-}$ mice had significantly increased extravasation of Evans Blue dye assessed $24 \mathrm{~h}$ after injury, indicating enhanced BBB permeability after TBI ( $n=5 /$ group). $\boldsymbol{B}$, Administration of the combination of IL- $1 \beta$ and TNF- $\alpha$ ( $8 \mu \mathrm{g} / \mathrm{kg}$ each) to brain-injured wildtype mice ( $n=6 /$ group) significantly increased BBB permeability $24 \mathrm{~h}$ after injury, as indicated by increased Evans Blue dye extravasation into the injured brain. ${ }^{*} p<0.05$ by Student's $t$ test. Data are presented as the mean \pm SEM.

times of administration were based upon those from a previous study that demonstrated that post-TBI administration of IL- $1 \beta$ worsens cortical tissue loss in rats (Utagawa et al., 2008). Figure $2 B$ shows that when the extravasation of Evans Blue dye was assessed $24 \mathrm{~h}$ after injury, the mice receiving exogenous IL-1 $\beta$ and TNF- $\alpha$ had significantly more dye in the injured cortex $(t=-3.639, p=0.005)$, indicating worsened BBB permeability.

\section{Postinjury administration of the nAChRa7 agonist PNU-} 282987 reduces circulating proinflammatory molecules As we observed that the loss of nAChRa7 increases circulating cytokine levels and exacerbates BBB permeability after TBI, we next examined whether stimulation of $\mathrm{nAChRa} 7$ can reduce TBIassociated levels of circulating IL- $1 \beta$, TNF- $\alpha$, HMGB-1, and IL-6. The nAChRa7 agonist PNU-282987 (3 mg/kg) or an equal volume of vehicle was intraperitoneally injected at $30 \mathrm{~min}, 12 \mathrm{~h}$, and $20 \mathrm{~h}$ after TBI into rats ( $n=5$ /group), and blood was withdrawn for the evaluation of cytokine levels (Fig. $3 A$ ). The delivered PNU-282987 dose was based on previous studies in which doses ranging from 0.3 to $10 \mathrm{mg} / \mathrm{kg}$ have been used in experimental models (Hijioka et al., 2012; Stuckenholz et al., 2013). As shown in Figure $3 B$, the plasma levels of IL- $1 \beta$ increase acutely after TBI, peaking $\sim 12 \mathrm{~h}$ after injury. Please note that IL- $1 \beta$ was measured using a traditional ELISA, which gave values that were lower than those detected using the multiplex approach (Fig. 1), a discrepancy that has been previously reported (Dupont et al., 2005). Compared with that seen in vehicle-treated injured animals, the level of IL- $1 \beta$ was found to be significantly reduced in injured animals treated with PNU-282987 (Fig. 3B; group main effect: $F=4.46, p=0.046)$. Although increases in circulating levels of TNF- $\alpha$ were observed after injury independent of treatment $(H=6.834, p=0.033)$, the levels of this cytokine were not significantly altered by PNU-282987 treatment (Fig. 3C; $F=$ $0.54, p=0.471)$. HMGB1 acts as a damage-associated molecular pattern molecule (DAMP) that triggers the release of inflammatory cytokines (by binding to toll-like receptor 4 ). The representative Western blot images in Figure $3 D$ show that the plasma samples from PNU-282987-treated injured animals have reduced HMGB-1 immunoreactivity compared with those detected in vehicle-treated, injured animals. In some samples, a nonspecific band corresponding to the migration of albumin was 
A

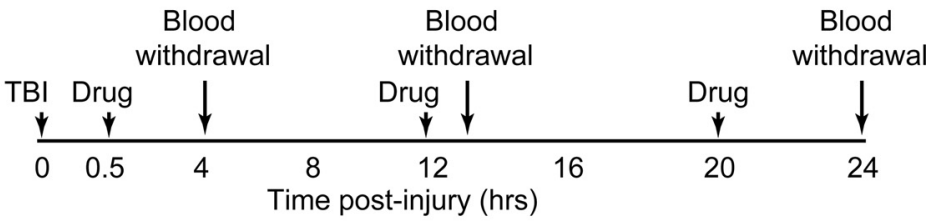

B

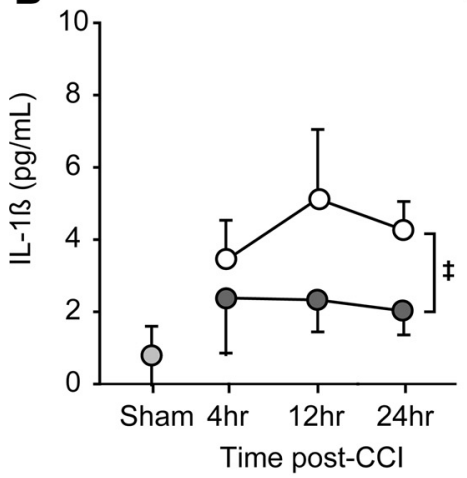

D

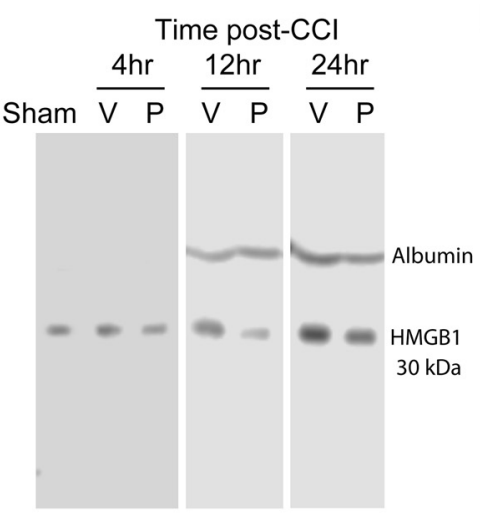

$\mathbf{F}$

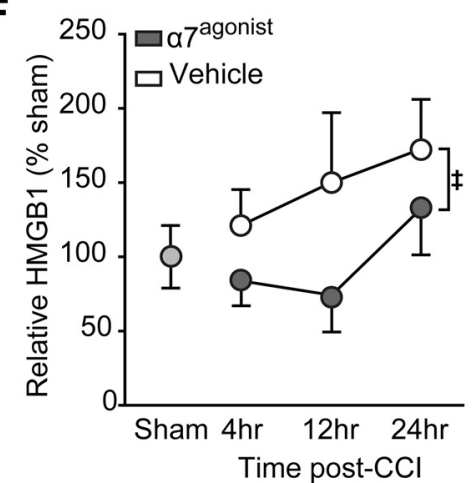

C

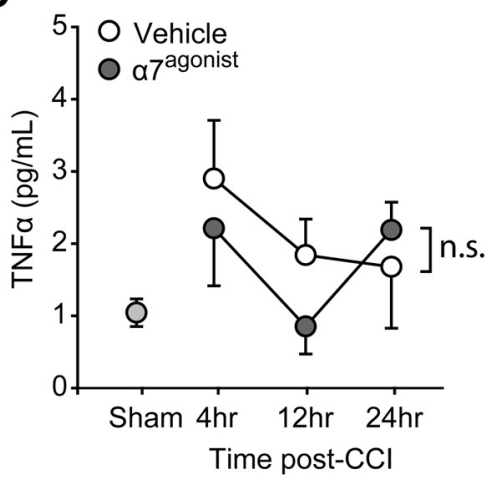

$\mathbf{E}$

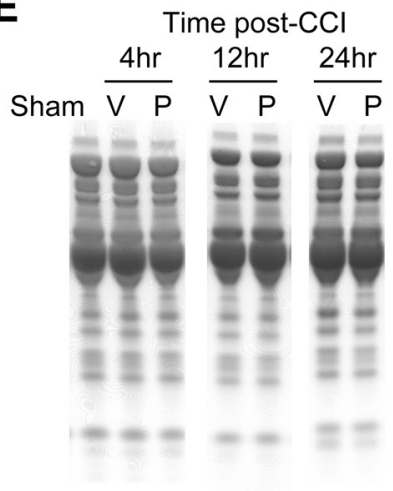

G

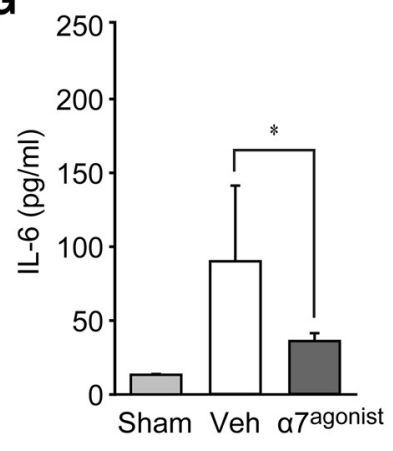

Figure 3. Post-TBI administration of the nAChRa7 agonist PNU-282987 decreases circulating levels of cytokines and HMGB-1. $\boldsymbol{A}$, Timeline for drug administration and blood collection after TBI. $\boldsymbol{B}$, The plasma levels of IL- $1 \beta$ were found to be significantly decreased at $12 \mathrm{~h}$ postinjury in animals treated with the nAChRa7 agonist PNU-282987 (3 mg/kg, i.p.; $\alpha 7^{\text {agonist }}$ ) compared with vehicle-treated injured animals ( $n=5 /$ time point/group). $C$, The plasma levels of TNF- $\alpha$ were found to be significantly increased after injury, but were not significantly altered by PNU-282987 ( $3 \mathrm{mg} / \mathrm{kg}$, i.p.; $\alpha 7^{\text {agonist})}$ administration ( $n=5 /$ time point/group). $\boldsymbol{D}$, Representative image of a composite Western blot showing HMGB1 immunoreactivity in the plasma of sham-injured animals treated with vehicle (V), and injured animals treated with PNU-282987 (P). Images were taken from three separate Western blots and combined for presentation. Sham samples were run on each membrane and used as a common comparator. $\boldsymbol{E}$, Representative images of Coomassie Blue-stained gels showing equality of loading. $\boldsymbol{F}$, Quantification of the $30 \mathrm{kDa}$ HMGB1 band revealed that postinjury administration of PNU-282987 significantly reduced (group main effect by two-way ANOVA) circulating HMGB1 levels ( $n=5 /$ time point/group). $G$, Compared with the levels detected in vehicle-treated injured animals, rats treated with PNU-282987 had significantly reduced plasma IL- 6 levels when assessed $6 \mathrm{~h}$ postinjury ( $n=3$ /group). $\neq$ Group main effect between vehicle- and PNU-282987-treated animals. Data are presented as the mean \pm SEM.

detected, presumably due to the abundance of this protein in serum and/or inefficient removal by the size exclusion column. Equality of loading was confirmed by colloidal Coomassie Blue staining (Fig. 3E). Quantification of HMGB-1 immunoreactivity, after normalization for protein loading, revealed that PNU282987 treatment significantly reduced HMGB-1 levels (group-main effect: $F=$ $4.74, p=0.041$; Fig. $3 F$ ). In separate animals killed $6 \mathrm{~h}$ after injury $(n=$ 3/group), TBI caused a significant increase in plasma IL-6 levels that was blunted as a result of PNU-282987 treatment (one-way ANOVA on ranks: $H=$ 5.96, $p=0.025$; Fig. $3 G$ ).

To examine whether PNU-282987 alters the infiltration of proinflammatory cells, brain tissue sections were prepared $48 \mathrm{~h}$ after the injury, and the presence of MPO-positive cells was examined (Fig. $4 A$ ). Figure $4 B$ shows that TBI causes a dramatic increase in MPO immunoreactivity in the ipsilateral cortex adjacent to the injury, as well as the ipsilateral hippocampus (data not shown). MPOpositive cells appeared to be both ramified and amoeboid in shape. Quantification of the number of amoeboid-shaped MPOpositive cells within the injured parietal cortex (from midline to the medial edge of the contusion) revealed that PNU-282987 significantly reduced the number of these cells, suggesting a reduction in infiltrating neutrophils $(F=41.92 ; p=0.006$; Fig. 4C). However, as both neutrophils and activated microglia can express MPO (Gray et al., 2008), we also examined the expression of $\mathrm{C}$ - $\mathrm{C}$ chemokine receptor type 2 (CCR2), as this receptor is expressed only by circulating monocytes/ macrophages and not by resident microglia (Morganti et al., 2015). CCR2positive cells could be seen in the vehicletreated injured animals, with fewer cells observed in the rats treated with PNU282987 (Fig. 4B). There was a statistically significant decrease in the number of CCR2-positive cells within the pericontusion region of the injured ipsilateral cortex as a result of PNU-282987 treatment $(F=36.70, p=0.008$; Fig. $4 D)$. No specific signal was observed when the primary antibodies were removed from the incubation mixture (data not shown).

Loss of nAChRa7 exacerbates, while nAChRa7 agonists reduce, TBItriggered $\mathrm{BBB}$ permeability

To test whether the stimulation of nAChRa7 can attenuate TBI-triggered $\mathrm{BBB}$ permeability, the $\mathrm{nAChRa7}$ agonist 
A

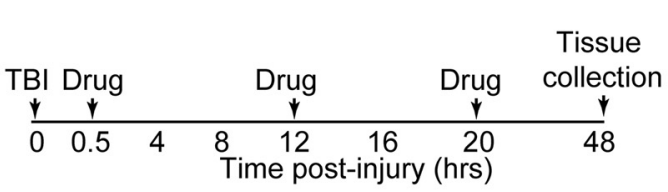

B
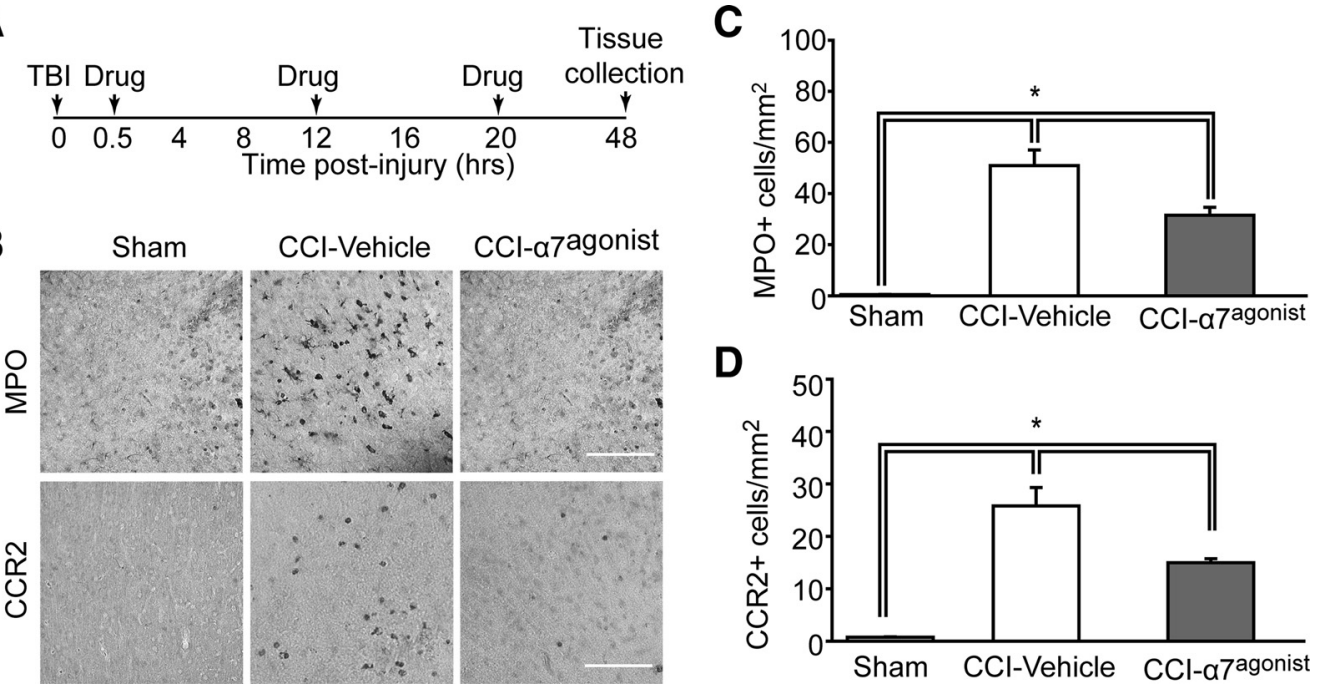

D

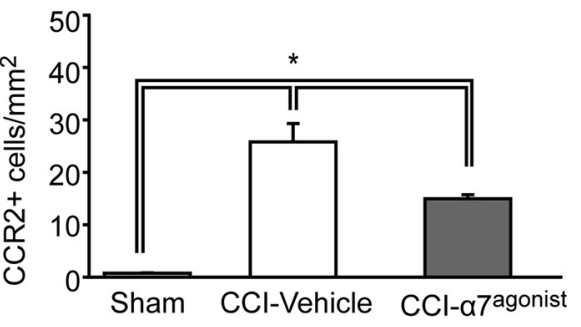

Figure 4. Post-TBI administration of the nAChRa7 agonist PNU-282987 decreases the infiltration of inflammatory cells into the injured brain. $A$, Timeline for $C(\mathrm{Cl}$, drug administration, and tissue collection after TBI. B, Photomicrographs of tissue taken from sham, vehicle-treated injured (CCl-vehicle) and PNU-282987-treated injured (CCl- $\alpha 7^{\text {agonist }}$ ) animals demonstrating MP0 and $C \mathrm{CR} 2$ immunoreactivity in the pericontusion area of the cortex $48 \mathrm{~h}$ after injury. C, Quantification of MPO-positive cells in the injured ipsilateral cortex after PNU-282987-treatment. D, Quantification of CCR2-positive cells in the injured ipsilateral cortex after PNU-282987-treatment. ${ }^{*} p<0.05$. Data are presented as the mean \pm SEM. Scale bar, $100 \mu \mathrm{m}$.

PNU-282987 (3 mg/kg; $n=8$ ) or vehicle $(n=9)$ was intraperitoneally injected to wild-type mice $30 \mathrm{~min}, 12 \mathrm{~h}$, and $20 \mathrm{~h}$ postinjury, with BBB integrity assessed $4 \mathrm{~h}$ after the last injection (Fig. 5A). Summary results presented in Figure $5 B$ shows that post-TBI administration of PNU-282987 significantly reduced $\mathrm{BBB}$ permeability $(t=5.469, p<0.001)$. To provide further support for the involvement of nAChRa7 in TBI-associated BBB compromise, we used PNU-120596, a type II-positive allosteric modulator that prevents receptor desensitization (Grønlien et al., 2007). Figure $5 C$ shows that when injured animals were treated with an injection of PNU-120596 (3 mg/kg, i.v., at $30 \mathrm{~min}$, $12 \mathrm{~h}$, and $20 \mathrm{~h}$ post-CCI; $n=8)$, a modest, but significant $(t=2.163, p=0.048)$ reduction in Evans Blue extravasation was observed compared with vehicle-injected injured controls $(n=8)$. Although PNU282987 has been reported to be a selective agonist of nAChRa7, its in vivo specificity of action can be questioned. We therefore tested whether the BBB-protective effect of PNU-282987 requires nAChRa7 using knock-out mice. When injured Chrna ${ }^{-1-}$ mice were treated with an injection of PNU-282987 (3 mg/kg, i.p., at $30 \mathrm{~min}, 12 \mathrm{~h}$, and $20 \mathrm{~h}$ post-CCI; $n=5$ /group), the BBB protective effect was lost $(t=0.925, p=0.382$; Fig. $5 D)$. This indicates that the observed BBB protective effect of PNU-282987 requires nAChRa7.

Immunohistochemical examination of endothelial cells (using von Willebrand factor immunoreactivity) and the tight junction protein Claudin -5 revealed that TBI markedly reduced the expression of these markers in the pericontusion region by $24 \mathrm{~h}$ after injury (Fig. 6A). Consistent with our Evans Blue dye extravasation results, the nAChRa7 agonist PNU-282987 (3 mg/kg, i.p., injected at $30 \mathrm{~min}, 12 \mathrm{~h}$, and $20 \mathrm{~h}$ post-CCI) appears to offer partial protection of these BBB components. Quantification of von Willebrand factor $(t=3.373, p=0.008$; Fig. $6 B$ ) and Claudin-5 ( $t=5.491, p<0.001$; Fig. $6 C)$ immunoreactivities revealed modest, but significant, increases of these markers in PNU-282987-treated injured mice compared with vehicletreated injured controls ( $n=4$ /group).

Intrasplenic injections of $\alpha$-bungarotoxin worsens, while the nAChRa7 agonist PNU-282987 decreases, TBI-induced BBB permeability

To specifically examine the role of nAChRa7 present on cells resident to the spleen, rats were given intrasplenic injections of $500 \mathrm{ng}$ of the nicotinic receptor blocker $\alpha$-bungarotoxin $20 \mathrm{~min}$ before CCI ( $n=5$; Fig. $7 A)$. Control animals underwent similar surgery and received an equal volume $(100 \mu \mathrm{l})$ of saline $(n=5)$. Rats were used for these studies due to their relatively larger 
A
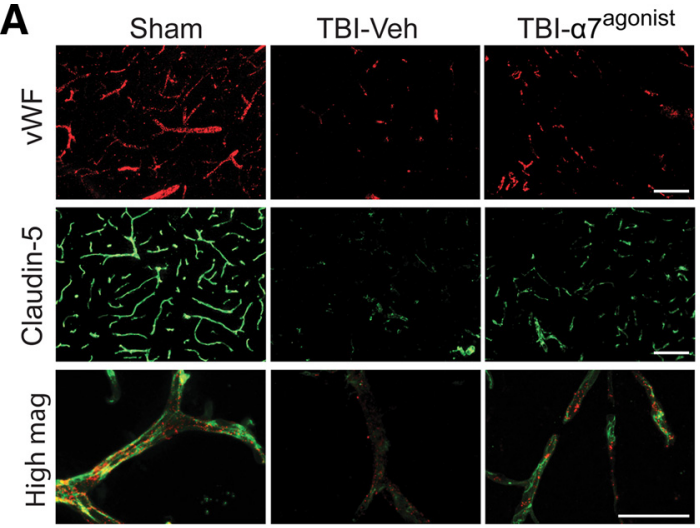

B

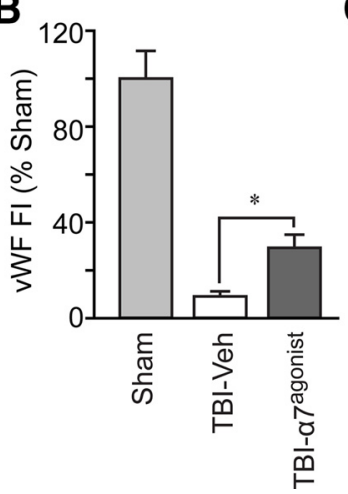

C

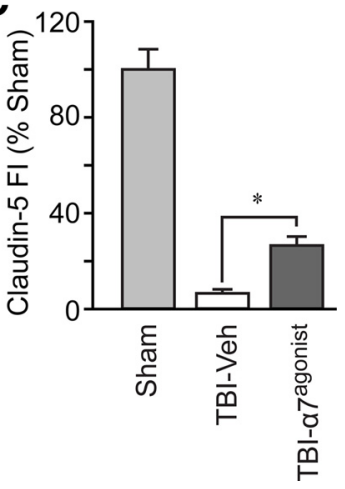

Figure 6. Postinjury administration of the $\mathrm{nAChRa7}$ agonist PNU-282987 reduces endothelial cell and tight junction protein loss in the injured cortex of mice. $\boldsymbol{A}$, Representative images of vWF (a marker of vascular endothelial cells) and the tight junction protein Claudin-5 immunoreactivity in tissue sections taken from a sham, a TBI animal treated with vehicle (TBI-Veh), and a TBI animal treated with PNU-282987 (3 mg/kg; TBI- $\alpha 7^{\text {agonist }}$ ). Images were taken from the pericontusion region of injured animals and the corresponding area from sham-injured animals. $\boldsymbol{B}, \boldsymbol{C}$, Summary data ( $n=4$ /group) show that systemic PNU-282987 administration reduced the loss of both vWF $(\boldsymbol{B})$ and Claudin-5 (C). ${ }^{*} p<0.05$ by $t$ test between vehicle- and PNU-282987-treated animals. Data are presented as the mean \pm SEM. Scale bars: lowmagnification images, $100 \mu \mathrm{m}$; high-magnification images, $20 \mu \mathrm{m}$.

spleen size. Figure $7 B$ shows that BBB permeability, assessed $24 \mathrm{~h}$ after injury, was significantly increased in the intrasplenic $\alpha$-bungarotoxin-injected animals $(t=-4.228, p=0.004)$. As the blockade of nicotinic receptors within the spleen increased TBIassociated BBB permeability, we next examined whether the activation of splenic nAChRa7 can reduce BBB permeability. The nAChRa7 agonist PNU-282987 (30 $\mu \mathrm{g} /$ spleen; $n=7)$ or an equivalent volume of vehicle $(n=8)$ was injected into the spleen of separate groups of rats $20 \mathrm{~min}$ before injury (Fig. 7A). Measurement of Evans Blue dye extravasation $24 \mathrm{~h}$ after injury revealed that intrasplenic administration of PNU-282987 significantly improved BBB integrity after TBI $(t=2.937, p=0.012$; Fig. $7 C$ ). While these studies implicate splenic nAChRa7 in regulating TBI-associated BBB permeability, it is possible that sources other than spleen significantly contribute to BBB breakdown after TBI. To address this possibility, we subcutaneously injected a group of splenectomized rats $(n=8)$ with $500 \mathrm{ng}$ of $\alpha$-bungarotoxin (to mimic the intrasplenic route of administration) $20 \mathrm{~min}$ before CCI. A second group of splenectomized rats $(n=8)$ was injured then injected intraperitoneally with $3 \mathrm{mg} / \mathrm{kg}$ PNU-282987 at $30 \mathrm{~min}, 12 \mathrm{~h}$, and $20 \mathrm{~h}$ after injury (a dose and a schedule that significantly reduced BBB permeability; Fig. 5A). A third group of splenectomized, injured rats received vehicle injections and were used as controls. BBB integrity was assessed
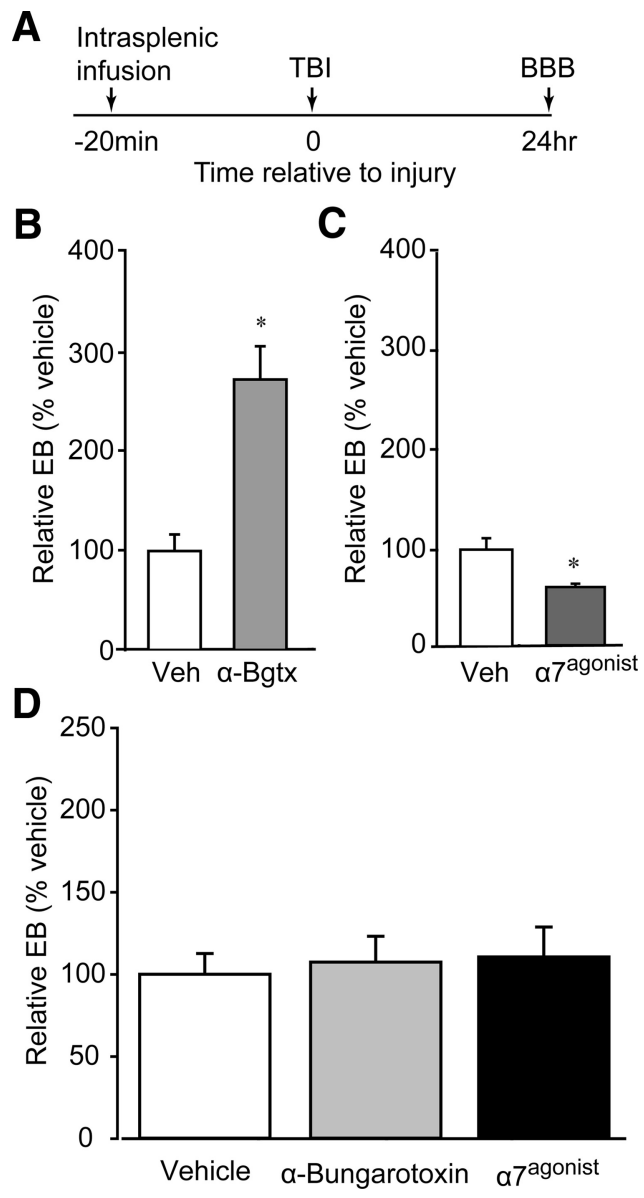

Figure 7. Intrasplenic injections of $\alpha$-bungarotoxin increase, while injections of the nAChRa7 agonist PNU-282987 decrease, TBI-induced BBB permeability. $\boldsymbol{A}$, Timeline for inrasplenic infusions, $\mathrm{CCl}$, and $\mathrm{BBB}$ assessment. $\boldsymbol{B}$, Summary results indicating that splenic injections of $\alpha$-bungarotoxin ( $\alpha$-Bgtx; $n=5$ ) significantly increase Evans Blue dye extravasation into the brain compared with injured animals receiving intrasplenic vehicle (Veh; $n=5)$ injections. $\boldsymbol{C}$, Intrasplenic injections of PNU-282987 (30 $\left.\mu \mathrm{g} ; \alpha 7^{\text {agonist }} ; n=7\right)$ significantly reduce Evans Blue dye extravasation compared with injured animals injected intrasplenically with vehicle $(n=8)$. ${ }^{*} p<0.05$ by $t$ test between vehicle- and $\alpha$-bungarotoxin-treated $(\boldsymbol{B})$ or PNU-282987-treated (C) animals. D, Evans Blue dye extravasation in splenectomized brain-injured rats treated with vehicle, $\alpha$-bungarotoxin (500 ng, s.c.), or PNU-282987 (3 mg/kg, i.p.) did not differ between the groups. Data are presented as the percentage vehicle-treated injured group; and data are reported as the mean \pm SEM.

$24 \mathrm{~h}$ after injury by examining the extravasation of Evans Blue dye. Figure $7 D$ shows that in the absence of the spleen, neither $\alpha$-bungarotoxin nor PNU-282987 had any significant influence on TBI-triggered BBB permeability $(F=0.121, p=0.887)$.

\section{Discussion}

Breakdown of the BBB is an important contributor to TBI pathology and outcome. While a few studies have examined the role of brain inflammation (Dietrich et al., 2004; Zhang et al., 2008; Haber et al., 2013; Chan et al., 2014; Faden et al., 2015), the contribution of systemic inflammation to TBI pathology has not been fully examined. The present investigation into TBI-induced BBB permeability revealed the following three key findings: (1) loss of nAChRa7 exacerbates systemic inflammation and BBB permeability; (2) stimulation of nAChRa7 using a selective agonist or a positive allosteric modulator reduces BBB permeability after injury; and (3) blockade of nAChRa7 within the spleen exacerbates, while their activation reduces, BBB permeability. Together, these findings indicate that short-term treatment with 
nAChRa7 receptor agonists and/or allosteric modulators may have clinical utility in reducing TBI-triggered BBB permeability (Fig. 8).

In agreement with a number of previous studies, we observed that the plasma levels of IL- $1 \beta$, TNF- $\alpha$, and IL- 6 were significantly elevated after CCI, with levels that remained above baseline for at least $6 \mathrm{~h}$ after injury (Fig. $3 B, G$ ). The magnitude of these changes is similar to those previously reported using CCI and weight-drop models (Li et al., 2011; Shein et al., 2014), and are comparable to the levels seen in human TBI patients. For example, we observed that CCI resulted in a mean plasma concentration of IL- 6 of 90 $\mathrm{pg} / \mathrm{ml}$ when assessed $6 \mathrm{~h}$ after injury. Previous studies of moderate-to-severe TBI in humans have reported that IL-6 levels increase dramatically within hours of injury, ranging from 80 to $100 \mathrm{pg} / \mathrm{ml}$ (Csuka et al., 1999; Berger et al., 2009). Although arterial/venous cytokine measurements have indicated that IL- 6 and IL-10, at least in part, may be released from the injured brain into the circulation, serum IL- $1 \beta$ and TNF- $\alpha$ likely have a peripheral origin after TBI (McKeating et al., 1997; Csuka et al., 1999). As systemic inflammation has been implicated in a variety of neurodegenerative diseases, and is thought to exacerbate damage following CNS insults, strategies to reduce systemic inflammation may have clinical relevance (Perry, 2010; Anthony and Couch, 2014; Amor et al., 2014).

A study by Utagawa et al. (2008) has shown that systemic, post-TBI administration of IL- $1 \beta$ markedly worsened cortical tissue loss and hippocampal neuronal damage. Consistent with these observations, we found that postinjury injection of IL- $1 \beta$ and TNF- $\alpha$ significantly worsened BBB permeability, suggesting that peripheral inflammation can be detrimental to TBI outcome. The vagus nerve is a key participant in the communication between the brain and components of the immune system, playing an important role in the regulation of peripheral inflammation. Consistent with this, vagus nerve stimulation has been demonstrated to decrease inflammation in models of sepsis and arthritis (Levine et al., 2014; Kox et al., 2015). For TBI, a brief 10 min stimulation of the vagus nerve immediately before experimental brain injury has been reported to decrease BBB permeability assessed $6 \mathrm{~h}$ later (Lopez et al., 2012). In addition, chronic intermittent vagus nerve stimulation initiated either 2 or $24 \mathrm{~h}$ after moderate fluid percussion injury has been shown to decrease cortical edema measured $48 \mathrm{~h}$ postinjury (Clough et al., 2007) and to protect against the loss of GABAergic neurons (Neese et al., 2007). Although the mechanism by which vagus nerve stimulation reduces BBB permeability and offers neuroprotection is yet to be determined, attenuation of post-traumatic seizures, reduction of excitotoxicity, and antiinflammatory effects have been proposed (Kumaria and Tolias, 2012). An important study by Borovikova et al. (2000) has demonstrated that vagus nerve stimulation has potent anti- inflammatory effects. This effect was subsequently shown to depend on ACh-mediated stimulation of nAChRa7 present on splenic macrophages (Rosas-Ballina et al., 2008). Based on these studies, we questioned whether nAChRa7 plays a role in TBIassociated inflammation and BBB permeability.

We demonstrate that mice lacking nAChRa7 have an exacerbated inflammatory response after TBI, as indicated by both enhanced levels of circulating cytokines and increased activation of microglia (as indicated by enhanced CD86 staining) within $24 \mathrm{~h}$ of injury. These increases were associated with worsened BBB permeability in $\mathrm{Chrna}^{-1-}$ mice compared with wild-type controls. In contrast to these findings, a previous study (Kelso et al., 2006) had examined the consequences of loss of nAChRa7 on microglia activation (using $\left[{ }^{3} \mathrm{H}\right]-\mathrm{PK} 11195$ binding and autoradiography), but did not report any significant findings when examined 1 week after moderate cortical impact injury. While the reason for this discrepancy is not known at present, it is plausible that the techniques used (CD86 immunohistochemistry versus $\left[{ }^{3} \mathrm{H}\right]$-PK11195 autoradiography) and/or the time points examined may have contributed to the differential findings.

Further supporting a role for nAChRa7 in TBI pathophysiology, we observed that systemic administration of the nAChRa7 agonist PNU-282987 significantly reduced circulating levels of IL- $1 \beta$ and IL- 6 , reduced the infiltration of macrophages and neu- 
trophils, and improved BBB integrity. The protective effect of PNU-282987 on BBB integrity was partially mimicked by the positive allosteric modulator of nAChRa7 PNU-120596 and lost in $\mathrm{Chrna7}^{-1-}$ mice. However, the global nature of these manipulations makes it difficult to ascribe a local or peripheral mechanism of action. Support for a role for splenic nAChRa7expressing cells on BBB permeability was demonstrated by intrasplenic administration of the nicotinic receptor antagonist $\alpha$-bungarotoxin, which exacerbated, while the nAChRa7 agonist PNU-282987 reduced, BBB permeability after TBI. Further, we demonstrated that the effects of $\alpha$-bungarotoxin and PNU282987 were lost in splenectomized rats, suggesting that these agents are not directly affecting the injured BBB.

Together, our experiments indicate that stimulation of nAChRa7 receptors can be used as a means of reducing TBIinduced peripheral inflammation and BBB permeability. However, some considerations must be taken into account before these findings can be translated into clinical use. First, although vagus nerve stimulation has been shown to improve outcome in animal models of traumatic brain injury, its effectiveness as a treatment in humans has yet to be determined (Shi et al., 2013). Second, nAChRa7 agonists can cause a rapid desensitization of nAChRa7 (Mazurov et al., 2006). Type II-positive allosteric modulators that potentiate nAChRa7 function without causing receptor desensitization (Bertrand and Gopalakrishnan, 2007) may be more suitable. Although not specific for nAChRa7 activation, Food and Drug Administration-approved acetylcholinesterase inhibitors (e.g., galantamine) can be used to stimulate nAChRa7 receptors and may have translational value. Further studies examining the dose-response relationship of these agents, their therapeutic time windows, and outcome would be required to determine whether these compounds can serve as suitable alternatives to vagus nerve stimulation.

\section{References}

Amor S, Peferoen LA, Vogel DY, Breur M, van der Valk P, Baker D, van Noort JM (2014) Inflammation in neurodegenerative diseases-an update. Immunology 142:151-166. CrossRef Medline

Anthony DC, Couch Y (2014) The systemic response to CNS injury. Exp Neurol 258:105-111. CrossRef Medline

Bazarian JJ, McClung J, Shah MN, Cheng YT, Flesher W, Kraus J (2005) Mild traumatic brain injury in the United States, 1998-2000. Brain Inj 19:85-91. CrossRef Medline

Bennett BR, Jacobs LM, Schwartz RJ (1989) Incidence, costs, and DRGbased reimbursement for traumatic brain injured patients: a 3-year experience. J Trauma 29:556-565. CrossRef Medline

Berger RP, Ta'asan S, Rand A, Lokshin A, Kochanek P (2009) Multiplex assessment of serum biomarker concentrations in well-appearing children with inflicted traumatic brain injury. Pediatr Res 65:97-102. CrossRef Medline

Bertrand D, Gopalakrishnan M (2007) Allosteric modulation of nicotinic acetylcholine receptors. Biochem Pharmacol 74:1155-1163. CrossRef Medline

Borovikova LV, Ivanova S, Zhang M, Yang H, Botchkina GI, Watkins LR, Wang H, Abumrad N, Eaton JW, Tracey KJ (2000) Vagus nerve stimulation attenuates the systemic inflammatory response to endotoxin. $\mathrm{Na}$ ture 405:458-462. CrossRef Medline

Bruchfeld A, Qureshi AR, Lindholm B, Barany P, Yang L, Stenvinkel P, Tracey KJ (2008) High Mobility Group Box Protein-1 correlates with renal function in chronic kidney disease (CKD). Mol Med 14:109-115. CrossRef Medline

Chan JL, Reeves TM, Phillips LL (2014) Osteopontin expression in acute immune response mediates hippocampal synaptogenesis and adaptive outcome following cortical brain injury. Exp Neurol 261:757-771. CrossRef Medline

Clough RW, Neese SL, Sherill LK, Tan AA, Duke A, Roosevelt RW, Browning RA, Smith DC (2007) Cortical edema in moderate fluid percussion brain injury is attenuated by vagus nerve stimulation. Neuroscience 147: 286-293. CrossRef Medline

Csuka E, Morganti-Kossmann MC, Lenzlinger PM, Joller H, Trentz O, Kossmann T (1999) IL-10 levels in cerebrospinal fluid and serum of patients with severe traumatic brain injury: relationship to IL-6, TNF-alpha, TGFbeta1 and blood-brain barrier function. J Neuroimmunol 101:211-221. CrossRef Medline

de Rivero Vaccari JP, Dietrich WD, Keane RW (2016) Therapeutics targeting the inflammasome after central nervous system injury. Transl Res 167:35-45. CrossRef Medline

Dietrich WD, Chatzipanteli K, Vitarbo E, Wada K, Kinoshita K (2004) The role of inflammatory processes in the pathophysiology and treatment of brain and spinal cord trauma. Acta Neurochir Suppl 89:69-74. Medline

Dixon CE, Clifton GL, Lighthall JW, Yaghmai AA, Hayes RL (1991) A controlled cortical impact model of traumatic brain injury in the rat. J Neurosci Methods 39:253-262. CrossRef Medline

Dupont NC, Wang K, Wadhwa PD, Culhane JF, Nelson EL (2005) Validation and comparison of luminex multiplex cytokine analysis kits with ELISA: determinations of a panel of nine cytokines in clinical sample culture supernatants. J Reprod Immunol 66:175-191. CrossRef Medline

Faden AI, Wu J, Stoica BA, Loane DJ (2015) Progressive inflammationmediated neurodegeneration after traumatic brain or spinal cord injury. Br J Pharmacol. Advance online publication. Retrieved February 3, 2016. doi:10.1111/bph.13179. CrossRef Medline

Gray E, Thomas TL, Betmouni S, Scolding N, Love S (2008) Elevated activity and microglial expression of myeloperoxidase in demyelinated cerebral cortex in multiple sclerosis. Brain Pathol 18:86-95. CrossRef Medline

Grønlien JH, Håkerud M, Ween H, Thorin-Hagene K, Briggs CA, Gopalakrishnan M, Malysz J (2007) Distinct profiles of alpha7 nAChR positive allosteric modulation revealed by structurally diverse chemotypes. Mol Pharmacol 72:715-724. CrossRef Medline

Haber M, Abdel Baki SG, Grin'kina NM, Irizarry R, Ershova A, Orsi S, Grill RJ, Dash P, Bergold PJ (2013) Minocycline plus N-acetylcysteine synergize to modulate inflammation and prevent cognitive and memory deficits in a rat model of mild traumatic brain injury. Exp Neurol 249: 169-177. CrossRef Medline

Heegaard W, Biros M (2007) Traumatic brain injury. Emerg Med Clin North Am 25:655-678, viii. CrossRef Medline

Helmy A, Carpenter KL, Menon DK, Pickard JD, Hutchinson PJ (2011) The cytokine response to human traumatic brain injury: temporal profiles and evidence for cerebral parenchymal production. J Cereb Blood Flow Metab 31:658-670. CrossRef Medline

Hijioka M, Matsushita $\mathrm{H}$, Ishibashi $\mathrm{H}$, Hisatsune A, Isohama $\mathrm{Y}$, Katsuki $\mathrm{H}$ (2012) alpha7 Nicotinic acetylcholine receptor agonist attenuates neuropathological changes associated with intracerebral hemorrhage in mice. Neuroscience 222:10-19. CrossRef Medline

Kelso ML, Wehner JM, Collins AC, Scheff SW, Pauly JR (2006) The pathophysiology of traumatic brain injury in alpha7 nicotinic cholinergic receptor knockout mice. Brain Res 1083:204-210. CrossRef Medline

Kinkade JM Jr, Pember SO, Barnes KC, Shapira R, Spitznagel JK, Martin LE (1983) Differential distribution of distinct forms of myeloperoxidase in different azurophilic granule subpopulations from human neutrophils. Biochem Biophys Res Commun 114:296-303. CrossRef Medline

Kochanek PM, Jackson TC, Ferguson NM, Carlson SW, Simon DW, Brockman EC, Ji J, Bayir H, Poloyac SM, Wagner AK, Kline AE, Empey PE, Clark RS, Jackson EK, Dixon CE (2015) Emerging therapies in traumatic brain injury. Semin Neurol 35:83-100. CrossRef Medline

Kossmann T, Stahel PF, Lenzlinger PM, Redl H, Dubs RW, Trentz O, Schlag G, Morganti-Kossmann MC (1997) Interleukin-8 released into the cerebrospinal fluid after brain injury is associated with blood-brain barrier dysfunction and nerve growth factor production. J Cereb Blood Flow Metab 17:280-289. CrossRef Medline

Kox M, van Eijk LT, Verhaak T, Frenzel T, Kiers HD, Gerretsen J, van der Hoeven JG, Kornet L, Scheiner A, Pickkers P (2015) Transvenous vagus nerve stimulation does not modulate the innate immune response during experimental human endotoxemia: a randomized controlled study. Arthritis Res Ther 17:150. CrossRef Medline

Kumaria A, Tolias CM (2012) Is there a role for vagus nerve stimulation therapy as a treatment of traumatic brain injury? Br J Neurosurg 26:316320. CrossRef Medline

Levine YA, Koopman FA, Faltys M, Caravaca A, Bendele A, Zitnik R, Vervoordeldonk MJ, Tak PP (2014) Neurostimulation of the cholinergic 
anti-inflammatory pathway ameliorates disease in rat collagen-induced arthritis. PLoS One 9:e104530. CrossRef Medline

Li M, Li F, Luo C, Shan Y, Zhang L, Qian Z, Zhu G, Lin J, Feng H (2011) Immediate splenectomy decreases mortality and improves cognitive function of rats after severe traumatic brain injury. J Trauma 71:141-147. CrossRef Medline

Loane DJ, Stoica BA, Tchantchou F, Kumar A, Barrett JP, Akintola T, Xue F, Conn PJ, Faden AI (2014) Novel mGluR5 positive allosteric modulator improves functional recovery, attenuates neurodegeneration, and alters microglial polarization after experimental traumatic brain injury. Neurotherapeutics 11:857-869. CrossRef Medline

Lopez NE, Krzyzaniak MJ, Costantini TW, Putnam J, Hageny AM, Eliceiri B, Coimbra R, Bansal V (2012) Vagal nerve stimulation decreases bloodbrain barrier disruption after traumatic brain injury. J Trauma Acute Care Surg 72:1562-1566. CrossRef Medline

Mazurov A, Hauser T, Miller CH (2006) Selective alpha7 nicotinic acetylcholine receptor ligands. Curr Med Chem 13:1567-1584. CrossRef Medline

McCrory P (2002) 2002 Refshauge Lecture. When to retire after concussion? J Sci Med Sport 5:169-182. CrossRef Medline

McKeating EG, Andrews PJ, Signorini DF, Mascia L (1997) Transcranial cytokine gradients in patients requiring intensive care after acute brain injury. Br J Anaesth 78:520-523. CrossRef Medline

Moreno A, López LA, Fabra A, Arús C (1998) 1H MRS markers of tumour growth in intrasplenic tumours and liver metastasis induced by injection of HT-29 cells in nude mice spleen. NMR Biomed 11:93-106. CrossRef Medline

Morganti JM, Jopson TD, Liu S, Riparip LK, Guandique CK, Gupta N, Ferguson AR, Rosi S (2015) CCR2 antagonism alters brain macrophage polarization and ameliorates cognitive dysfunction induced by traumatic brain injury. J Neurosci 35:748-760. CrossRef Medline

Morganti-Kossmann MC, Rancan M, Stahel PF, Kossmann T (2002) Inflammatory response in acute traumatic brain injury: a double-edged sword. Curr Opin Crit Care 8:101-105. CrossRef Medline

Morganti-Kossmann MC, Satgunaseelan L, Bye N, Kossmann T (2007) Modulation of immune response by head injury. Injury 38:1392-1400. CrossRef Medline

Neese SL, Sherill LK, Tan AA, Roosevelt RW, Browning RA, Smith DC, Duke A, Clough RW (2007) Vagus nerve stimulation may protect GABAergic neurons following traumatic brain injury in rats: an immunocytochemical study. Brain Res 1128:157-163. CrossRef Medline

Nolan S (2005) Traumatic brain injury: a review. Crit Care Nurs Q 28: 188-194. CrossRef Medline

Olofsson PS, Rosas-Ballina M, Levine YA, Tracey KJ (2012) Rethinking inflammation: neural circuits in the regulation of immunity. Immunol Rev 248:188-204. CrossRef Medline

Pavlov VA, Tracey KJ (2006) Controlling inflammation: the cholinergic anti-inflammatory pathway. Biochem Soc Trans 34:1037-1040. CrossRef Medline

Perry VH (2010) Contribution of systemic inflammation to chronic neurodegeneration. Acta Neuropathol 120:277-286. CrossRef Medline

Raghupathi R (2004) Cell death mechanisms following traumatic brain injury. Brain Pathol 14:215-222. CrossRef Medline

Rosas-Ballina M, Ochani M, Parrish WR, Ochani K, Harris YT, Huston JM, Chavan S, Tracey KJ (2008) Splenic nerve is required for cholinergic antiinflammatory pathway control of TNF in endotoxemia. Proc Natl Acad Sci U S A 105:11008-11013. CrossRef Medline

Rosas-Ballina M, Olofsson PS, Ochani M, Valdés-Ferrer SI, Levine YA, Rear- don C, Tusche MW, Pavlov VA, Andersson U, Chavan S, Mak TW, Tracey KJ (2011) Acetylcholine-synthesizing T cells relay neural signals in a vagus nerve circuit. Science 334:98-101. CrossRef Medline

Sanderson KL, Raghupathi R, Saatman KE, Martin D, Miller G, McIntosh TK (1999) Interleukin-1 receptor antagonist attenuates regional neuronal cell death and cognitive dysfunction after experimental brain injury. J Cereb Blood Flow Metab 19:1118-1125. CrossRef Medline

Shein SL, Shellington DK, Exo JL, Jackson TC, Wisniewski SR, Jackson EK, Vagni VA, Bayir H, Clark RS, Dixon CE, Janesko-Feldman KL, Kochanek PM (2014) Hemorrhagic shock shifts the serum cytokine profile from pro- to anti-inflammatory after experimental traumatic brain injury in mice. J Neurotrauma 31:1386-1395. CrossRef Medline

Shi C, Flanagan SR, Samadani U (2013) Vagus nerve stimulation to augment recovery from severe traumatic brain injury impeding consciousness: a prospective pilot clinical trial. Neurol Res 35:263-276. CrossRef Medline

Stahel PF, Shohami E, Younis FM, Kariya K, Otto VI, Lenzlinger PM, Grosjean MB, Eugster HP, Trentz O, Kossmann T, Morganti-Kossmann MC (2000) Experimental closed head injury: analysis of neurological outcome, bloodbrain barrier dysfunction, intracranial neutrophil infiltration, and neuronal cell death in mice deficient in genes for pro-inflammatory cytokines. J Cereb Blood Flow Metab 20:369-380. Medline

Stuckenholz V, Bacher M, Balzer-Geldsetzer M, Alvarez-Fischer D, Oertel WH, Dodel RC, Noelker C (2013) The alpha7 nAChR agonist PNU282987 reduces inflammation and MPTP-induced nigral dopaminergic cell loss in mice. J Parkinsons Dis 3:161-172. CrossRef Medline

Tanno H, Nockels RP, Pitts LH, Noble LJ (1992) Breakdown of the bloodbrain barrier after fluid percussive brain injury in the rat. Part 1: distribution and time course of protein extravasation. J Neurotrauma 9:21-32. CrossRef Medline

Titus DJ, Sakurai A, Kang Y, Furones C, Jergova S, Santos R, Sick TJ, Atkins CM (2013) Phosphodiesterase inhibition rescues chronic cognitive deficits induced by traumatic brain injury. J Neurosci 33:5216-5226. CrossRef Medline

Turtzo LC, Lescher J, Janes L, Dean DD, Budde MD, Frank JA (2014) Macrophagic and microglial responses after focal traumatic brain injury in the female rat. J Neuroinflammation 11:82. CrossRef Medline

Utagawa A, Truettner JS, Dietrich WD, Bramlett HM (2008) Systemic inflammation exacerbates behavioral and histopathological consequences of isolated traumatic brain injury in rats. Exp Neurol 211:283-291. CrossRef Medline

Walker PA, Shah SK, Jimenez F, Gerber MH, Xue H, Cutrone R, Hamilton JA, Mays RW, Deans R, Pati S, Dash PK, Cox CS Jr (2010) Intravenous multipotent adult progenitor cell therapy for traumatic brain injury: preserving the blood brain barrier via an interaction with splenocytes. Exp Neurol 225:341-352. CrossRef Medline

Wang H, Yu M, Ochani M, Amella CA, Tanovic M, Susarla S, Li JH, Wang H, Yang H, Ulloa L, Al-Abed Y, Czura CJ, Tracey KJ (2003) Nicotinic acetylcholine receptor alpha7 subunit is an essential regulator of inflammation. Nature 421:384-388. CrossRef Medline

Zhang B, West EJ, Van KC, Gurkoff GG, Zhou J, Zhang XM, Kozikowski AP, Lyeth BG (2008) HDAC inhibitor increases histone H3 acetylation and reduces microglia inflammatory response following traumatic brain injury in rats. Brain Res 1226:181-191. CrossRef Medline

Zhao J, Moore AN, Redell JB, Dash PK (2007) Enhancing expression of Nrf2-driven genes protects the blood brain barrier after brain injury. J Neurosci 27:10240-10248. CrossRef Medline 